\title{
Allelopathy of Bidens sulphurea L. aqueous extracts on lettuce development.
}

CRUZ-SILVA, C.T.A. ${ }^{*}$; NASU, E.G.C. ${ }^{2}$; PACHECO, F.P. ; NOBREGA, L.H.P. ${ }^{1}$

1 Programa de Pós-graduação em Engenharia Agrícola, Universidade Estadual do Oeste do Paraná, UNIOESTE, Cascavel, Paraná, Brasil. ' Curso de Ciências Biológicas, Universidade Paranaense, UNIPAR, Campus Cascavel. *Autor para correspondência: claudia_petsmart@hotmail.com

ABSTRACT: Allelochemical compounds are present in tissues of different plants ' parts and also in other organisms, being released into the environment and thus affecting plants development. There is evidence that secondary metabolites produced by weeds may exhibit several allelopathic effects. This study aimed to evaluate allelopathic activity based on the interaction of aqueous extracts preparations and their concentrations obtained from Bidens sulphurea (Cav.) Sch. Bip. leaves on germination and seedlings development of Lactuca sativa L. cv. Grand rapids (lettuce). The extracts were obtained from fresh leaves and prepared by infusion, decoction, leaching and grinding methods, at concentrations of $0,7.5,15,22.5$ and $30 \%$, with four replications with 25 lettuce seeds. Seven days after the percentages of abnormal seedlings and germination, shoot and root length $(\mathrm{cm})$ were evaluated, while germination speed index (GSI) was daily determined and calculated. The experiment was completely randomized in a $4 \times 5$ factorial design, with four extract preparation methods and 5 concentrations. It was found out that the $B$. sulphurea aqueous extracts did not affect the germination and abnormal seedling development percentages in lettuce seeds. The aqueous extracts and their concentrations showed allelopathic effect for GSI, shoot and root length variables, despite their methods of preparation. This effect is not only inhibitory, but in some cases it was also stimulatory.

Keywords: lettuce, weed, germination, growth.

RESUMO: Alelopatia de extratos aquosos de Bidens sulphurea L. no desenvolvimento de alface. Os aleloquímicos são compostos que estão presentes nos tecidos de diferentes partes das plantas e outros organismos, são liberados no ambiente e atuam no desenvolvimento das mesmas. Existem evidências de que os metabólitos secundários produzidos por plantas invasoras podem apresentar uma variedade de efeitos alelopáticos. O presente estudo objetivou avaliar a atividade alelopática através de interação das formas de preparo dos extratos aquosos e suas concentrações obtidas de folhas de Bidens sulphurea (Cav.) Sch. Bip. sobre a germinação e o desenvolvimento de plântulas de Lactuca sativa L. cv. Grand rapids (alface). Os extratos foram obtidos de folhas frescas e preparados sob a forma de infusão, decocção, maceração estática e trituração, nas concentrações de $0 ; 7,5 ; 15 ; 22,5$ e 30\%, com quatro repetições com 25 sementes de alface. Após sete dias foi avaliado a porcentagem de germinação e plântulas anormais, comprimento da parte aérea e raiz $(\mathrm{cm})$, sendo diariamente as sementes avaliadas para o calculo do índice de velocidade de germinação (IVG). O delineamento experimental foi inteiramente casualizado, organizado em esquema fatorial $4 \times 5$, com 4 formas de preparo dos extratos e 5 concentrações. Foi possível constatar que os extratos aquosos de $B$. sulphurea não influenciaram o percentual de germinação e formação de plântulas anormais em sementes de alface. As diferentes formas de obtenção dos extratos aquosos e suas concentrações apresentaram efeito alelopático para as variáveis IVG, crescimento da parte aérea e comprimento da raiz não sendo o efeito somente inibitório, mas em alguns casos também de estímulo.

Palavras chave: plantas invasoras, germinação, crescimento. 


\section{INTRODUCTION}

The term allelopathy defines a chemicalecological phenomenon in which secondary metabolites, produced by a plant species, are released into the environment and interferes on germination of other plants stage (Soares et al., 2002). All plants produce them; however, vary in quantity and quality from species to species. The tolerance or resistance to these compounds can also be specified and there is more sensitive species than others, such as lettuce (Lactuca sativa L.) and tomato (Lycopersicon esculentum Mill.), which are used in bioassays as allelopathy bioindicators (Ferreira \& Aquila, 2000).

In plants, the allelopathic substances play many different roles, such as preventing seed decomposition, interfering in their dormancy as well as in stem buds and influence their relations with other plants (Durigan \& Almeida, 1993).

The chemical compounds are present in seeds, roots, stems and branches of plants in different amounts, with a tendency to accumulate in leaves, due to the fact that most studies show that leaves have higher allelopathic potential than other plant fractions (Souza Filho et al., 2011). The release of these compounds into the environment occurs by volatilization, leaching, exudation by roots and plant residues decomposition (Souza, 1998; Reigosa et al., 1999; Goldfarb et al., 2009).

Allelopathic effects and action mechanism of allelochemicals are fundamentals to understand the interactions among plants, either in natural systems, or in agricultural systems. These may have several implications in agriculture by the effects that allelochemicals can cause as well as by the effects they are submitted in the environment. Plants can produce allelopathic substances and their chemical nature differs among species, as well as their susceptibility to allelochemicals released by other plants. As a result of this variability, some species are favored and others suffered, which may affect the specific and quantitative composition of weed communities (Durigan \& Almeida, 1993).

From the agriculture point of view, studies regarding to allelopathic effects and plants identification with such effect have assumed particular importance since the knowledge of crops and weeds allelopathic relationships will improve agricultural systems through the most suitable techniques adoption such as cultivars choice, crop rotation, period and sowing processes (Gomide, 1993). According to Pires \& Oliveira (2001), there are several weed species with allelopathic potential. These plants can contribute to the control of others through exudates, leachates and volatiles production.

Allelopathic effects of weed species on different crops were found in scientific researches.
Bhowmik \& Doll (1982) observed that aqueous extract of Amaranthus retroflexus dry residue inhibited maize root length and soybean hypocotyl. Stevens \& Tang (1987) showed that Bidens pilosa reduced seedling growth of lettuce, beans, corn and sorghum, which was considered by Rabêlo et al. (2008) and Gusman et al. (2011) a species with allelopathic potential.

There is evidence that secondary metabolites, produced by weed may show a wide variety of allelopathic effects. The Bidens genus has more than 15 species of importance around the world and Bidens pilosa $\mathrm{L}$. has the greatest transcendence, which is a weed present in most Latin American countries that infest annual and perennial crops (Lorenzi, 2000).

The Bidens genus, popularly known as beggarticks, has been used to cure many health problems, is used for herbal medicine, mainly for liver problems (hepatitis and jaundice), whose leaves are mostly used (Vasques et al., 1986; Botsaris, 2007). There are repored the greatest incidence of polyacetylenes (34\%), chalcones (12\%), phenylpropanoids $(9 \%)$, flavonols $(9 \%)$, thiophene derivatives (9\%) and aurones (5\%) in Bidens genus (Emerenciano et al., 2006; Emerenciano et al., 2001).

Bidens sulphurea (Cav.) Sch. Bip. species belongs to Asteraceae family and is an annual herb, native from Mexico, widely distributed in Brazil. It is important ornamental potential and, also cited as a weed due to its effective dissemination and growth (Lorenzi \& Souza, 2008).

This study aimed to evaluate allelopathic activity based on the interaction of aqueous extracts preparations and their concentrations obtained from $B$. sulphurea leaves on germination and seedlings development of Lactuca sativa L. Cv. Grand rapids.

\section{MATERIAL AND METHODS}

The trials were carried out at Botany and Plant Physiology Laboratories as well as in greenhouse of Paranaense University (UNIPAR), Campus of Cascavel, Paraná State. Bidens sulphurea fresh leaves were collected during their reproductive period and used as donor plant material. The seeds used as receivers were lettuce (Lactuca sativa L. variety Grand rapids), acquired in agricultural shops.

Thirty grams of fresh $B$. sulphurea leaves were grinded, infused, decocted, and each fraction was dipped in $100 \mathrm{~mL}$ of distilled water, and filtered to produce $30 \%$ aqueous extract (stock solution). Dilutions to $7.5,15$ and $22.5 \%$ were prepared and distilled water was used as the control treatment. 
All $\mathrm{pH}$ concentrations were recorded for analysis of possible interference, with digital pHmeter.

The preparation of water extract fractions was according to the following: 1 - fresh leaves were weighed, washed, chopped into $1 \mathrm{~cm}$ pieces and ground for two minutes, decocted for two minutes, to prepare ground and decocted extracts, respectively; 2 - fresh leaves were weighed, washed, chopped into $1 \mathrm{~cm}$ pieces and kept into water for 24 hours, to obtain the leachate aqueous extract; fresh leaves were weighed, washed, chopped into $1 \mathrm{~cm}$ pieces and placed in a beaker, added boiling deionized water for five minutes to obtain infusion extract.

In laboratory, $9 \mathrm{~cm}$-diameter Petri dishes were used, covered with two filter paper sheets and planted to 25 lettuce seeds to constitute the plots. In each dish, $10 \mathrm{~mL} B$. sulphurea aqueous extract was added and it was used distilled water as untreated check. The Petri dishes were kept in a germination chamber at constant temperature $\left(20 \pm 2{ }^{\circ} \mathrm{C}\right)$ and 16 hour light photoperiod. The germination chamber, counters and other materials were previously disinfected with $70 \%$ alcohol; Petri dishes and filter paper were autoclaved at $120^{\circ} \mathrm{C}$ for 20 minutes.

Numbers of germinated seeds were counted every day to calculate the germination speed index (GSI) (Borghetti \& Ferreira, 2004). The seeds with roots equal or greater than $2 \mathrm{~mm}$ were considered germinated. After seven days, the final evaluation was held in order to consider the following variables: shoot and root length $(\mathrm{cm})$, germination percentage and abnormal seedlings (with root necrosis).

The experiment was completely randomized, in $4 \times 5$ factorial design with four extract preparations (grinding, leaching, infusion and decoction) and five concentrations $(0,7.5,15,22.5$ and $30 \%)$ for each obtained extracts way. Each treatment was carried out with four replications, 25 lettuce seeds, with 100 seeds per treatment. Data were submitted to analysis of variance (ANOVA) and averages were compared by Tukey test at $5 \%$ probability using the $\mathrm{R}$ software (R Development Core Team, 2014).

\section{RESULTS AND DISCUSSION}

The $\mathrm{pH}$ of aqueous extracts from $B$. sulphurea leaves, for all tested concentrations, showed variations among 5.8 and 7.22 . It is likely that the $\mathrm{pH}$ of aqueous extracts have not contributed to change the results (Table 1). Cardoso (2004) and Kerbauy (2004) recommended that the $\mathrm{pH}$ should be from 6.0 to 7.5 range; since many biochemical processes occurred in these $\mathrm{pH}$ conditions.

Interactions between preparation method and extracts concentration did not affect germination of lettuce seeds that varied from 93 to $100 \%$ (Table 2).

Borghetti \& Ferreira (2004) stated that allelopathy may not affect percentage of seed germination, but on germination speed index (GSI). This was observed in this study, by reducing the GSI of seeds treated with the extracts obtained from 15; 22.5 and $30 \%$ decoction when compared with the control treatment and some preparation methods, with dose-response dependent. Thus, as the concentration increased, there was a decrease on GSI. Aoki et al. (1997) point out that the intensity of allelopathic effects is dependent on the substances concentration.

Similarly to what was found out in this trial, Gusman et al. (2011) have tested aqueous extracts of three weeds (Bidens pilosa L., Cyperus rotundus L. and Euphorbia heterophylla L.) regardless the target tested species (tomato, lettuce, cabbage or radish) and observed that the germination process was the least affected by extracts when compared with GSI and seedling initial development. The authors emphasize that from the studied three weeds, B. pilosa showed greater allelopathic potential, which is the same genus of species used in this study.

Leachate extract increased the GSI for $7.5 \%$ concentration when compared with the control treatment. According to Borghetti \& Ferreira (2004) the highest the GSI, the greatest the germination speed, which can be inferred that the seed lot is more vigorous. So, the extract prepared by leaching promoted an increase in germination potential of lettuce seeds.

The $22.5 \%$ concentration of ground extract differed from control treatment and 7.5\% concentration reducing seeds GSI. Extracts prepared by infusion showed no significant statistic difference among concentrations. Infusion preparation method at higher concentration increased GI when compared with higher concentration of decoction method.

Similarly, Pelegrini \& Cruz-Silva (2012) used the same extracts preparation methods and tested concentrations in this trial from fresh leaves

Table 1. $\mathrm{pH}$ values obtained from concentrations of $B$. Sulphurea aqueous extracts

\begin{tabular}{cllllll}
\hline \multicolumn{2}{c}{ Extract/Concentration } & 0 & 7.5 & 15 & 22.5 & 30 \\
\multirow{3}{*}{ B. sulphurea } & Ground & 7.22 & 6.48 & 6.24 & 6.14 & 6.05 \\
& Leachate & 7.22 & 6.68 & 6.53 & 6.50 & 6.45 \\
& Infusion & 6.70 & 6.42 & 6.40 & 6.35 & 6.27 \\
& Decoction & 6.70 & 6.30 & 6.06 & 5.94 & 5.80 \\
\hline
\end{tabular}

Rev. Bras. PI. Med., Campinas, v.17, n.4, supl. I, p.679-684, 2015. 
TABLE 2. Preparation methods and aqueous extracts concentrations of Bidens sulphurea (Cav.) Sch. Bip. leaves on Lactuca sativa seeds development.

\begin{tabular}{|c|c|c|c|c|c|c|}
\hline \multirow[t]{2}{*}{ Variables } & \multirow[t]{2}{*}{ Extracts } & \multicolumn{5}{|c|}{ Concentrations (\% w/v) } \\
\hline & & 0 & 7.5 & 15 & 22.5 & 30 \\
\hline & Ground ns & 98 & 95 & 97 & 97 & 98 \\
\hline \multirow[t]{4}{*}{ Germination \% } & Leachate ns & 98 & 100 & 100 & 97 & 99 \\
\hline & Infusion ns & 99 & 99 & 94 & 94 & 98 \\
\hline & Decoction ns & 99 & 94 & 94 & 93 & 98 \\
\hline & Ground & 22.92aA & $22.13 a \mathrm{~A}$ & $20.60 a b A B$ & $18.50 \mathrm{bBC}$ & 19.88abA \\
\hline \multirow[t]{4}{*}{ GSI } & Leachate & $20.41 \mathrm{bA}$ & 24.13aA & 23.13abA & 21.54abA & 22.88abA \\
\hline & Infusion & $23.48 \mathrm{aA}$ & $23.21 \mathrm{aA}$ & $22.21 \mathrm{aA}$ & $22.13 a A$ & $22.50 \mathrm{aA}$ \\
\hline & Decoction & 23.48aA & 20.71abA & $18.56 \mathrm{bcB}$ & $15.33 \mathrm{cdC}$ & $12.96 \mathrm{~dB}$ \\
\hline & Ground & $3.99 \mathrm{bA}$ & $4.95 a \mathrm{~A}$ & $3.44 \mathrm{cB}$ & $2.16 \mathrm{dC}$ & $2.26 \mathrm{~dB}$ \\
\hline & Leachate & $3.99 \mathrm{cA}$ & $4.72 \mathrm{bA}$ & $4.63 \mathrm{bA}$ & $4.44 \mathrm{bA}$ & $5.26 \mathrm{aA}$ \\
\hline \multirow{3}{*}{$(\mathrm{cm})$} & Infusion & $4.18 \mathrm{aA}$ & $3.35 \mathrm{bB}$ & $2.11 \mathrm{dC}$ & $2.60 \mathrm{cB}$ & $1.00 \mathrm{eC}$ \\
\hline & Decoction & $4.18 \mathrm{aA}$ & $1.19 \mathrm{bc}$ & $0.86 \mathrm{bcD}$ & $0.76 \mathrm{cdD}$ & $0.43 \mathrm{dD}$ \\
\hline & Ground & $1.87 \mathrm{bA}$ & $2.63 a A$ & $2.60 \mathrm{aA}$ & $2.46 \mathrm{aA}$ & $2.58 \mathrm{aA}$ \\
\hline \multirow[t]{3}{*}{ Shoot Length $(\mathrm{cm})$} & Leachate & $1.87 \mathrm{cA}$ & $1.97 \mathrm{bcB}$ & $2.15 \mathrm{abB}$ & $2.30 \mathrm{aA}$ & $2.22 \mathrm{aB}$ \\
\hline & Infusion & $1.50 \mathrm{aB}$ & 1.39abC & $1.20 \mathrm{cC}$ & $1.31 \mathrm{abcB}$ & $1.27 \mathrm{bcC}$ \\
\hline & Decoction & $1.50 \mathrm{aB}$ & $1.39 \mathrm{aC}$ & $1.06 \mathrm{bC}$ & $1.05 \mathrm{bC}$ & $0.77 \mathrm{cD}$ \\
\hline \multirow[t]{4}{*}{ Abnormal Seedling \% } & Ground ns & 0 & 0.01 & 0 & 0.02 & 0 \\
\hline & Leachate ns & 0 & 0.01 & 0 & 0.01 & 0 \\
\hline & Infusion ns & 0 & 0.01 & 0 & 0.01 & 0 \\
\hline & Decoction ns & 0 & 0.01 & 0 & 0.01 & 0 \\
\hline
\end{tabular}

Note: Averages followed by the same lower-case letter in a row and capital letter in a column, did not differ significantly according to Tukey test at $5 \%$ probability. ns: not significant. GI: germination index.

of Coleus barbatus on GSI of lettuce seedlings, in order to observe stability of infusion extract in different concentrations.

When the preparation methods are compared with the extracts concentrations, it was verified that 0 and $7.5 \%$ concentrations showed no variation on GSI. There were no statistical differences among preparation methods, except for the $22.5 \%$ concentration. Extracts prepared by grinding, infusion and decoction also showed no significant statistic difference among preparation methods concerning the concentration level.

Root growth was stimulated by ground extract in lower concentration (7.5\%) and inhibited at higher concentrations when compared with control. This difference in concentrations was observed by Gatti et al. (2004) when used aqueous extracts of Aristolochia esperanzae root and stem and observed that they stimulated the lettuce root length up to $50 \%$ concentration, while the same extracts inhibited the length at $100 \%$ concentration.

Rabêlo et al. (2008) found out that aqueous extracts of $B$. pilosa dried leaves (obtained by grinding) reduced shoots and roots growth of all tested species (cabbage, turnip, lettuce (five cultivars) and radish). The extract when simulated leaching differed significantly from the control treatment, with a considerable root growth in all tested concentrations, and 30\% concentration showed a better performance. The extracts obtained by infusion and decoction inhibited root growth in all tested concentrations when compared with the control, and there were statistics differences among concentrations within infusion extract.

These results agree with those obtained by Corrêa et al. (2005), who used aqueous extracts of B. pilosa dried leaves obtained by grinding and infusion and tested on lettuce and soybean development. The authors found out that the extracts inhibited the root length in both preparation methods, up from 1 or $2 \%$ concentration according to the studied species.

The leachate extract showed the best averages of root growth for $15,22.5$ and $30 \%$ concentrations and differed significantly from the others when it was analyzed preparation method based on concentration level. On the other hand, the decoction extract showed the lowest averages of root growth. There was a significant difference from the other extraction methods in all concentrations, except for the control treatment. 
The higher the extract concentration, the higher the inhibitory effect caused in ground, infusion and decoction extracts. This was in accordance with the results obtained by Bhatt et al. (2001), who have tested allelopathic effects of weeds such as $B$. pilosa. In order to test leguminous and cereal germinations, it was found out that the aqueous extracts of these plants reduced the germination and inhibited the root length and plumule of all studied species. At last, the allelopathic effect increased with an increasing extract concentration.

Viecelli \& Cruz-Silva (2009) tested preparation methods and extract concentrations and associated them with the lettuce roots developments that were affected by the extracts differently: sometimes stimulating, sometimes inhibiting their growth. This response variation was due to the way of the extracts methods obtained, the tested concentrations and the season when the leaves were collected.

The ground extract stimulated shoot length for all tested concentrations when compared with the control in this following order: $41,39,32$ and $38 \%$, for $7.5 ; 15 ; 22.5$ and $30 \%$ concentrations, respectively (Table 2). Concentrations from 15 to $30 \%$ leachate extract of $B$. sulphurea leaves stimulated shoot growth when compared with the control, whereas the extracts concentrations by infusion and decoction inhibited the shoot system growth. Simoneto \& Cruz-Silva (2010) observed inhibition of maize and sunflower root growth and tomato and sunflower shoots under extract prepared from leaves infusion of sage (Salvia officinalis L.).

Singh \& Hazarika (1996) observed that aqueous extracts of Galinsoga parviflora and $B$. pilosa showed inhibitory effects on germination, root and shoot growth of soybean and beans, suggesting that the compounds are released into the environment by its decomposition in soil. The ground and leachate extracts showed the highest values for shoot growth in all tested concentrations and differed significantly when compared with extracts prepared by infusion and decoction. For all extracts and concentrations, the abnormal seedlings observation was not significant.

Pelegrini \& Cruz-Silva (2012) pointed out that the lettuce development was affected by the preparation methods and concentration of Coleus barbatus (A.) Benth. leaves extracts. There was some stimulation of shoot growth seedling by ground, leachate and decoction extracts, while no response of root growth.

Finally, decoction extracts showed the lowest averages of GSI, roots and shoots growth variables, followed by infusion extract. The leachate extract increased significantly lettuce seedlings growth. Oliveira et al. (2004) also reported that it is not ensured if shoot growth reduction is a direct result of allelochemicals actions or a consequence of the roots growth reduction.

The different methods of obtaining extracts induce different secondary metabolites, according to the molecule characteristics, which probably affects the response pattern of variables submitted to different extracts. According to Falkenberg et al. (2007), the temperature increase causes an increase in substances solubility, so, the heat extraction methods are faster than those performed at room temperature. However, the heat extraction plus the extracts obtained by infusion and decoction induced greater availability of allelopathic compounds. These data, as mentioned above, were those ones that negatively affected some parameters evaluated in this trial.

Several organic compounds were identified as allelochemicals, produced by microorganisms or plants (Rice, 1984), and among them, there are polyacetylenes, flavonoids, phenylpropanoids (cinnamic acid derivative compounds), which are compounds found in Bidens genus.

Souza Filho et al. (2009) pointed out that Ocimum americanum $\mathrm{L}$. oil affects germination, root and hypocotyl development of Mimosa pudica L. and Senna obtusifolia (L.) HS Irwin \& Barneby and related that the observed effects can be attributed to the presence of phenylpropanoids among other compounds in its essential oil.

Chalcones, also found in Bidens genus, were cited for presenting allelopathic effect (chalcone SC - 2,4'-dimetoxichalcone) that inhibited the seeds germination of M. pudica and S. obtusifolia, in 58 and $48 \%$, respectively, at $300 \mathrm{mg} \mathrm{L}^{-1}$ concentration (Bitencourt et al., 2007).

Based on the results obtained in this study, it was found out that the aqueous extracts of Bidens sulphurea leaves did not affect the percentage of germination and abnormal seedlings development of lettuce. The different methods of obtaining the studied aqueous extracts and their concentrations showed allelopathic effects on germination speed index, shoot and root growth variables. Another important answer was that there was not only an inhibitory effect, but in some cases, also stimulus.

\section{REFERENCE}

AOKI, T. et al. Biologically active clerodane-type diterpene glycosides from the root-stalks of Dicranopteris pedata. Phytochemistry, v. 46, n. 5, p. 839-844, 1997.

BHATT, B.P. et al. Allelopathic effects of weeds on germination and growth of legumes and cereal crops of North Eastern Himalayas. Allelopathy Journal, v.8, n 2, p. 225-232, 2001.

BHOWMIK, P.C.; DOLL, J.D. Corn and soybean response

Rev. Bras. Pl. Med., Campinas, v.17, n.4, supl. I, p.679-684, 2015. 
to allelopathic effects of weed and crop residues. Agronomy Journal, v. 74, p. 601-606, 1982.

BITENCOURT, H.R. et al. Atividade alelopática de chalcona sintética, de seus precursores e de cetonas e aldeídos relacionados. Planta daninha, v.25, n.4, p. 747-753, 2007.

BORGHETTI, F.; FERREIRA, A.G. Interpretação de resultados de germinação. In: FERREIRA, A. G.; BORGHETTI, F. (Ed.) Germinação do básico ao aplicado. 2.ed. Porto Alegre: Artmed, 2004. p. 209-222.

BOTSARIS, A.S. Plants used traditionally to treat malária in Brazil: the archives of flora medicinal. Journal of Ethnobiology and Ethnomedicine, v.3, n.18, p. 2007. CARDOSO, V.J.M. Germinação. In: KERBAUY, G. B. Fisiologia vegetal. Rio de Janeiro: Guanabara Koogan, 2004. p.387-408.

CORRÊA, J.M. et al. Efeito alelopático de extratos aquosos de picão preto (Bidens pilosa L.) sobre a alface (Lactuca sativa L.) e soja (Glycine max (L.) Merrill). In: 4응 ENCONTRO DE INICIAÇÃO CIENTÍFICA, $2^{\circ}$ FÓRUM DE PESQUISA E $2^{\circ}$ ENCONTRO PARANAENSE DE ÉTICA, 2005, Umuarama, PR. Anais... Umuarama: UNIPAR, 2005. 430p.

DURIGAN, J.C., ALMEIDA, F.S Noções sobre a alelopatia. Jaboticabal, UNESP/FUNEP, 1993. 28 p. (Boletim Técnico).

EMERENCIANO, V.P. et al. Flavonoids as chemotaxonomic markers for Asteraceae. Biochemical Systematics and Ecology, v. 29, p. 947-957, 2001.

EMERENCIANO, V.P. et al. Principal component analysis of Heliantheae (Asteraceae) Sensu Stuessy and Karis and Ryding based on chemical data. Natural Products an Indian Journal, v. 2, p. 35-44, 2006.

FALKENBERG, M.B. et al. Introdução à análise fitoquímica. In: SIMÕES, C.M.O. et al. (Org.). Farmacognosia: da planta ao medicamento. 6.ed. Florianópolis: UFSC; Porto UFRGS, 2007. P.229-245.

FERREIRA, A.G.; ÁQUILA, M.E.A. Alelopatia: Uma área emergente da ecofisiologia. Brasília: Revista Brasileira de Fisiologia Vegetal, v. 12, edição especial, p.175-204, 2000.

GATTI. A.B. et al. Atividade alelopática de extratos aquosos de Aristolochia esperanzae O. Kuntze na germinação e mo crescimento de Lactuca sativa L. e Raphanus sativus L. Acta Botanica Brasilica, v.18, n.6, p.459-472, 2004.

GOLDFARB, M. et al. Alelopatia: relações nos agroecossistemas. Tecnologia \& Ciência Agropecuária, v. 3, n. 1, p. 23-28, 2009.

GOMIDE, M.B. Potencialidades alelopáticas dos restos culturais de dois cultivares de cana-de-açúcar (Saccharum sp.), no controle de algumas plantas daninhas. Piracicaba: ESALQ, 1993. 96p. Dissertação (Mestrado em Fitotecnia)-Escola Superior de Agronomia Luiz de Queiroz, 1993.

GUSMAN, G.A. et al. Potencial alelopático de extratos aquosos de Bidens pilosa L., Cyperus rotundus L. e Euphorbia heterophylla L. Iheringia, Série Botânica., v. 66, n. 1, p. 87 - 98, 2011.

KERBAUY, G. B. Fisiologia vegetal. 1.ed. Rio de Janeiro: Guanabara Koogan, 2004. 452p.

LORENZI, H.; SOUZA, H. M. Plantas ornamentais no Brasil: arbustivas, herbáceas e trepadeiras. 4.ed.
Nova Odessa: Instituto Plantarum, 2008. 1088p.

LORENZI, H. Manual de identificação e controle de plantas daninhas: plantio direto e convencional. 5.ed. Nova Odessa: Instituto Plantarum, 2000. 339 p.

OLIVEIRA, S.C.C. et al. Efeito alelopático de folhas de Solanum lycocarpum A. St. Hil. (Solanaceae) na germinação e crescimento de Sesamum indicum L. (Pedaliaceae) sob diferentes temperaturas. Acta Botânica Brasílica, v.18, n. 3, p. 401-406, 2004.

PELEGRINI, L.L.; CRUZ-SILVA, C.T.A. Variação sazonal na alelopatia de extratos aquosos de Coleus barbatus (A.) Benth. sobre a germinação e o desenvolvimento de Lactuca sativa L. Revista Brasileira de Plantas Medicinais, v.14, n.2, p.376-382, 2012.

PIRES, N.M.; OLIVEIRA, V.R. Alelopatia. In: OLIVEIRA, R. S.; CONSTANTIN, J. Plantas daninhas e seu manejo. Agropecuária: Guaíba, 2001. p. 145-185.

RABÊLO, G.O. et al. Potencial alelopático de Bidens pilosa L.na germinação e no desenvolvimento de espécies cultivadas. Revista Científica da Faminas, v. 4, n.1, p. 33-43, 2008.

R DEVELOPMENT CORE TEAM. R: A language and environment for statistical computing. $R$ Foundation for Statistical Computing, Vienna, Austria. ISBN 3-900051-07-0, 2014. Disponível em: <http://www.Rproject.org>. Acesso em: 14 fev. 2014.

REIGOSA, M.J. et al. Ecophysiological approach in allelopathy. Critical Reviews in Plant Sciences, v.18, n.5, p.577-608, 1999.

RICE, E.L. Allelopathy. 2 ed. Orlando: Academic Press, 1984. 422p.

SIMONETO, E.L.; CRUZ-SILVA, C.T.A. Alelopatia de sálvia sobre a germinação e o desenvolvimento do milho, tomate e girassol. Cultivando o Saber, v.3, n.3, p.48-56, 2010.

SINGH, R.; HAZARIKA, U.K. Allelopathic effects of Galinsoga parviflora Car. and Bidens pilosa L. on germination and seedling growth of soybean and groundnut. Allelopathy Journal, v.3, n.1, p. 89-92, 1996.

SOARES, G.L.G. et al. Potencial alelopático do extrato aquoso de folhas de algumas leguminosas arbóreas brasileiras. Floresta e Ambiente, v.9, n.1, p.119-125, 2002.

SOUZA, I. F. Controle de plantas daninhas. Lavras-MG: UFLA, 1998. 54p.

SOUZA FILHO, A.P.S. et al. Atividade potencialmente alelopática do óleo essencial de Ocimum americanum. Planta daninha, v.27, n.3, p. 499-505, 2009.

SOUZA FILHO, A.P.S. et al. Sementes como fonte alternativa de substâncias químicas com atividade alelopática. Planta daninha, v.29, n.3, p. 709-716, 2011.

STEVENS, G.A.; TANG, C.S. Inhibition of crop seedling growth by hydrophobic root exudates of the weed Bidens pilosa. Journal of Tropical Ecology, v. 3, p. 91-94, 1987.

VASQUES, C.A.V. et al. Revisão farmacognóstica do picão (Bidens pilosa L.). Arquivos Brasileiros de Medicina, v.60, n.2, p.107-108, 1986.

VIECELLI, A.C.; CRUZ-SILVA, C.A.T. Efeito da variação sazonal no potencial alelopático de Sálvia. Semina: Ciências agrárias, v.30, n.1, p.39-46, 2009.

Rev. Bras. PI. Med., Campinas, v.17, n.4, supl. I, p.679-684, 2015. 